\title{
CALCULATION OF THERMOPHYSICAL PROPERTIES OF OILS AND TRIACYLGLYCEROLS USING AN EXTENDED CONSTITUENT FRAGMENTS APPROACH
}

\author{
CÁLCULO DE PROPIEDADES TERMOFÍSICAS DE ACEITES Y \\ TRIACILGLICEROLES EMPLEANDO UNA METODOLOGİA \\ EXTENDIDA DE FRAGMENTOS
}

Diana-Carolina Cruz-Forero ${ }^{1}$, Oscar-Andrés González-Ruiz ${ }^{1}$ and Luis-Javier López-Giraldo ${ }^{1 *}$ 1 Universidad Industrial de Santander, Bucaramanga, Santander, Colombia

e-mail: ljlopez@uis.edu.co

(Received Jul. 05, 2012; Accepted Nov. 09, 2012)

\begin{abstract}
$\mathrm{T}$

This paper validates and implements an Extended Constituent Fragments methodology (ECF) for the calculation of thermophysical properties of vegetable oils considering the latter as triglyceride (TAG's) mixtures, both homogeneous and heterogeneous. For this purpose, three different vegetables oils were chosen (soybean oil, canola and olive) and their TAG's profiles were estimated using the ECN 42 generalized method. The ECF methodology estimates the properties of TAG's from their fragment composition and specific parameters of each property, which are adjusted using experimental information available in literature. The average relative errors of calculated properties were between 1 and $32 \%$ depending on the oil and the property. These errors were significantly lower than those obtained using the Aspen HYSYS commercial software, which oscillates between 70 and 100\%. Additionally, by extrapolating the constituent fragments methodology a method for calculating boiling temperatures of TAG's with average relative errors of $\sim 1 \%$ was proposed. The calculations of properties for the ECF method were performed using the OIL-CALPROP software developed specifically for this purpose.
\end{abstract}

Keywords: Vegetable oils, Triglycerides, Prediction, Thermodynamic properties, Calorific capacity, Boiling temperature, Simulation, Software.

How to cite: Cruz-Forero, D. C., González-Ruíz, O. A. \& López-Giraldo, L. J. (2012). Calculation of thermophysical properties of oils and triacylglycerols using an extended constituent fragments approach. CT\&F - Ciencia, Tecnología y Futuro, 5(1), 67-82.

*To whom correspondence should be addressed

+ V Congreso Internacional de Ciencia y Tecnología de los Biocombustibles, CIBSCOL 2012, Universidad Industrial de Santander, Bucaramanga, Santander, Colombia. 5 - 8 de junio de 2012. 


\section{RESUMEN}

n este trabajo se valida e implementa la metodología de Fragmentos Constituyentes Extendida (FCE)
al cálculo de propiedades termofísicas de aceites vegetales considerando a éstos últimos como
mezclas de triglicéridos (TAG's) tanto homogéneos como heterogéneos. Para tal fin, se seleccionan
tres aceites modelo (aceite de soja, canola y oliva) a los cuales se les estimaron los perfiles en TAG's, a
partir de su perfil en ácidos grasos empleando el método ECN 42 generalizado. Con el método de FCE se
estiman las propiedades de los TAG's a partir de la composición en fragmentos y parámetros específicos de
cada propiedad, los cuales son ajustados empleando información experimental disponible en la literatura.
Los errores relativos promedio de las propiedades calculadas fluctúan entre el 1 y el $32 \%$ dependiendo del
aceite y la propiedad. Estos errores son significativamente menores que los obtenidos empleando el software
comercial Aspen HYSYS los cuales oscilan entre 70 y $100 \%$.Adicionalmente, extrapolando la metodología de
fragmentos constituyentes, se propuso un método que permite el cálculo de temperaturas de ebullición de
TAG's con errores relativos promedio de $\sim 1 \%$. Los cálculos de propiedades para el método FCE se realizaron
usando el software OIL-CALPROP desarrollado específicamente para este propósito.

Palabras clave: Aceites vegetales, Triglicéridos, Predicción, Propiedades termodinámicas, Capacidad calorífica, Temperatura de ebullición, Simulación, Software.

\section{RESUMO}

este trabalho se valida e implementa a metodologia de Fragmentos Constituintes Estendida (FCE) ao cálculo de propriedades termofísicas de óleos vegetais considerando a estes últimos como misturas de triglicerídeos (TAG's) tanto homogêneos como heterogêneos. Para tal fim, selecionam-se três óleos modelo (óleo de soja, canola e oliva) aos quais foram estimados os perfis em TAG's, a partir do seu perfil em ácidos grassos empregando o método ECN 42 generalizado. Com o método de FCE se estimam as propriedades dos TAG's a partir da composição em fragmentos e parâmetros específicos de cada propriedade, os quais são ajustados empregando informação experimental disponível na literatura. Os erros relativos médio das propriedades calculadas flutuam entre 1 e $32 \%$ dependendo do óleo e a propriedade. Estes erros são significativamente menores que os obtidos empregando o software comercial Aspen HYSYS os quais oscilam entre 70 e 100\%. Adicionalmente, extrapolando a metodologia de fragmentos constituintes, foi proposto um método que permite o cálculo de temperaturas de ebulição de TAG's com erros relativos médio de $\sim 1 \%$. Os cálculos de propriedades para o método FCE foram realizados usando o software OILCALPROP desenvolvido especificamente para este propósito.

Palavras chave: Óleos vegetais, Triglicerídeos, Predição, Propriedades termodinâmicas, Capacidade calorífica, Temperatura de ebulição, Simulação, Software. 


\section{INTRODUCTION}

The growth of population and technological development has made recent years those of greater energy increases in history. This growth has begun to generate concern due to the prospect of depletion, in the near future, of existing oil reserves. Fortunately, despite being the most widely used, fossil energy is not the only source of energy available to meet this demand. Biodiesel, for example, has become one of the most highly researched energy options in recent years, and it has proven to be a viable and cost-effective alternative. In the specific case of Colombia, between 2009 and 2010, its production had a $126 \%$ increase (United States Energy Information Administration, 2011). Biodiesel can be produced from more than 300 species of different oilseeds. However, soil conditions, climate, yield, oil content and the need to mechanize production, limit the potential of obtaining vegetable oils to a few species among which palm, rapeseed, sunflower, soybean and microalgae stand out (Ministerio de Agricultura y Desarrollo Rural, 2010; Chisti, 2007).

Despite its potential, the implementation of a process for large scale production of biodiesel must be validated through its simulation, for which it is necessary to know the thermodynamic and transport properties of the compounds involved. However, many of these thermodynamic properties are not available for the oils that are commonly used for the production of biodiesel.

To overcome this limitation, predictive methods and thermodynamic models that allow for calculating the properties needed for the simulation of process trends have been used (Díaz-Tovar, Gani \& Sarup, 2011). One of the most commonly used simulators for the calculation of properties and modeling of processes in the industry is Aspen HYSYS ${ }^{\circledR}$.

Despite the fact that this software is recommended especially for the hydrocarbon industry, Aspen HYSYS ${ }^{\circledR}$ is commonly used for the simulation of processes for biodiesel production (among other bio-fuels) a fact widely evident in available literature (West, Posarac \& Ellis, 2008; Martinho et al., 2008; Santana et al., 2010; Lee, Posarac \& Ellis, 2011; Anitescu \& Bruno, 2012; Santori, di Nicola, Moglie \& Polonara, 2012). However, this simulation software has no databases containing the properties of oils or the triglycerides that constitute them, forcing the assumption that the single compound defined in this data base (triolein) is the constituent of the oil which process is being simulated. An alternative method of calculation is the Constituent Fragments model (CF) (Zong, Ramanathan \& Chen, 2010a; Zong, Ramanathan \& Chen, 2010b) that considers triglycerides as the grouping of a central column (glycerol) and three carbonated chains (fatty acids). However, in their work Zong et al. (2010a) considered oils as a mixture of homogeneous triglycerides.

As a result, one of the objectives of this work is to evaluate the impact of homogeneous and heterogeneous TAG's on the accuracy of estimates of the thermophysical and transport properties of oils (specific calorific capacity, density, viscosity and vapor pressure), designing a computational tool for their calculation. In addition, extrapolating the CF methodology, we propose a method for the calculation of TAG's boiling temperatures $(\mathrm{Tb})$.

\section{METHODOLOGY}

Although the CF method allows for calculating the thermophysical properties of heterogeneous TAG's, Zong et al. (2010a) only validated his work using oils defined by homogeneous TAG's profiles. As shown in Figures 1 and 2, data entry is the main difference between the methods. Since the ECF method supports starting the calculation from the fatty acids profile of a vegetable oil, it allows for greater flexibility and an expanded TAG's spectrum, which in theory would lead to more accurate results. Furthermore, the methodology proposed here offers the possibility of calculating the boiling temperatures of the TAG's that constitute the oil.

A computational tool (OIL-CALPROP, version 1.0) that supports the estimation of the thermophysical properties (i.e. calorific capacity, density, viscosity, vapor pressure) of oils constituted by mixtures of both homogeneous and heterogeneous TAG's was initially designed to validate the reliability of the results obtained using the above mentioned ECF method.

Once the values for the thermophysical properties of soybean, canola and olive oils were estimated, they 


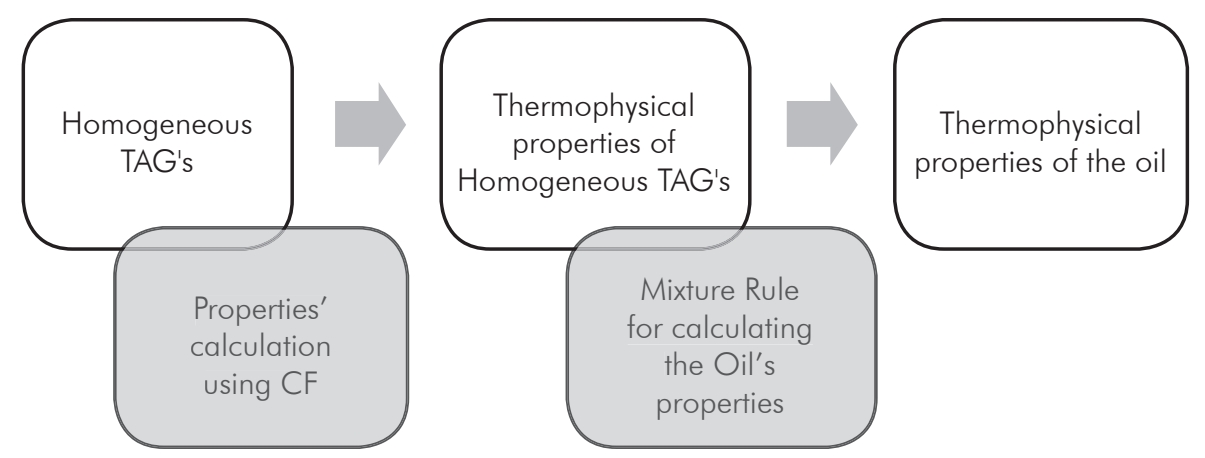

Figure 1. Simplified flowchart for the calculation of thermophysical properties using the Constituent Fragments (CF) method proposed by Zong et al. (2010a). Here, the white and grey boxes represent input or output information and methodological actions respectively.

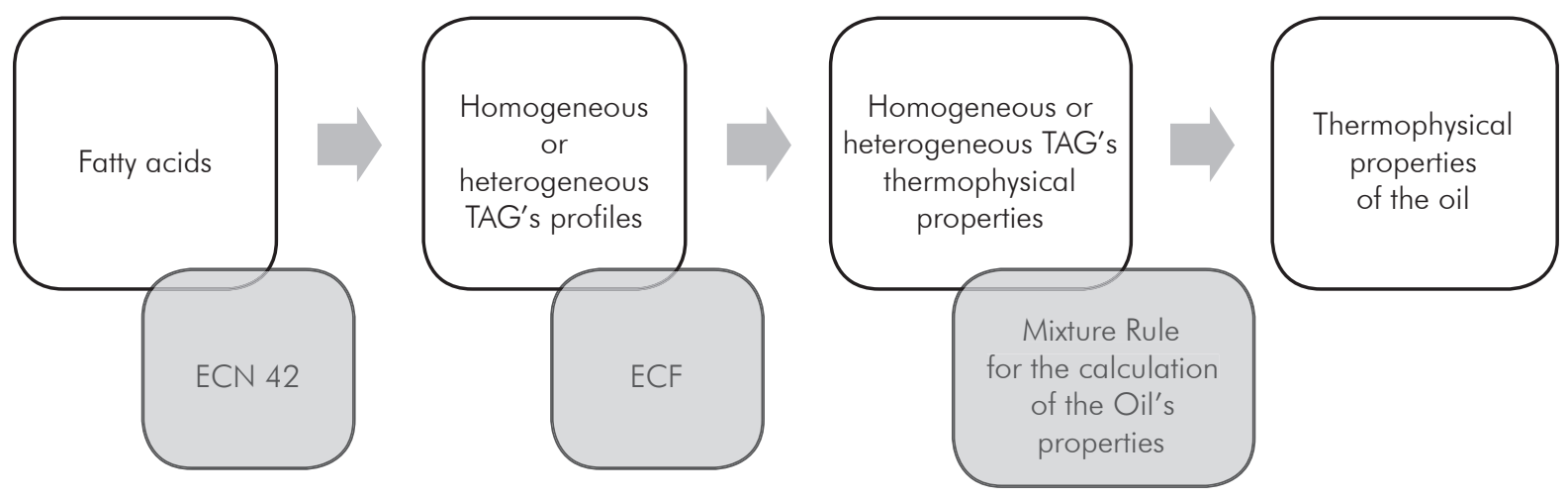

Figure 2. Simplified flowchart for the calculation of thermophysical properties using the Extended Constituent Fragments (ECF) method. Here, the white and grey boxes represent input or output information and methodological actions, respectively.

were compared to the values obtained using commercial software (Aspen HYSYS ${ }^{\circledR}$, version 7.2), to the values calculated using the original method proposed by Zong et al. (2010a) and to experimental data reported in the literature. It should be noted that calculations obtained using the Aspen HYSYS ${ }^{\circledR}$ simulator had a purely comparative function in the reliability study of the results obtained by the ECF method. The estimation of TAG's profiles from its fatty acids composition was carried out using the ECN 42 method (Figure 2) (Panreac Química S.A., 1999).

For the scope of this article only the results obtained for the properties of soybean oil will be reported.

Proposal and Development of the Computational Tool for Calculation of the Thermophysical Properties of Oils (OIL-CALPROP, version 1.0)

The VISUAL BASIC ${ }^{\circledR}$ STUDIO 2010 simulation interface (Ultimate version) was used for proposal and development of the tool. The logical sequence used is shown in Figures 3 and 4. Both the sequence and the program are divided into two processes; the first is the entry of data that will allow for defining the oil to be evaluated, and the second is the calculation of properties using the ECF method.

\section{Characterization of the TAG's Profile for Each Oil}

Despite the fact that the soybean oil TAG's profile is relatively easy to find in the literature that information is not available for the oils used in the production of biodiesel. However, it is very common to have available their fatty acids' profiles, from which it is possible to reconstruct the TAG's composition using the ECN 42 method (Panreac Química S.A, 1999). As a result, this methodology was used for implementation of a computational routine which allows for calculating the approximate TAG's composition of oils from their fatty acid content. As an example, the soybean oil's representative (greater than 5\%) fatty acid profile is shown in Table 1. 


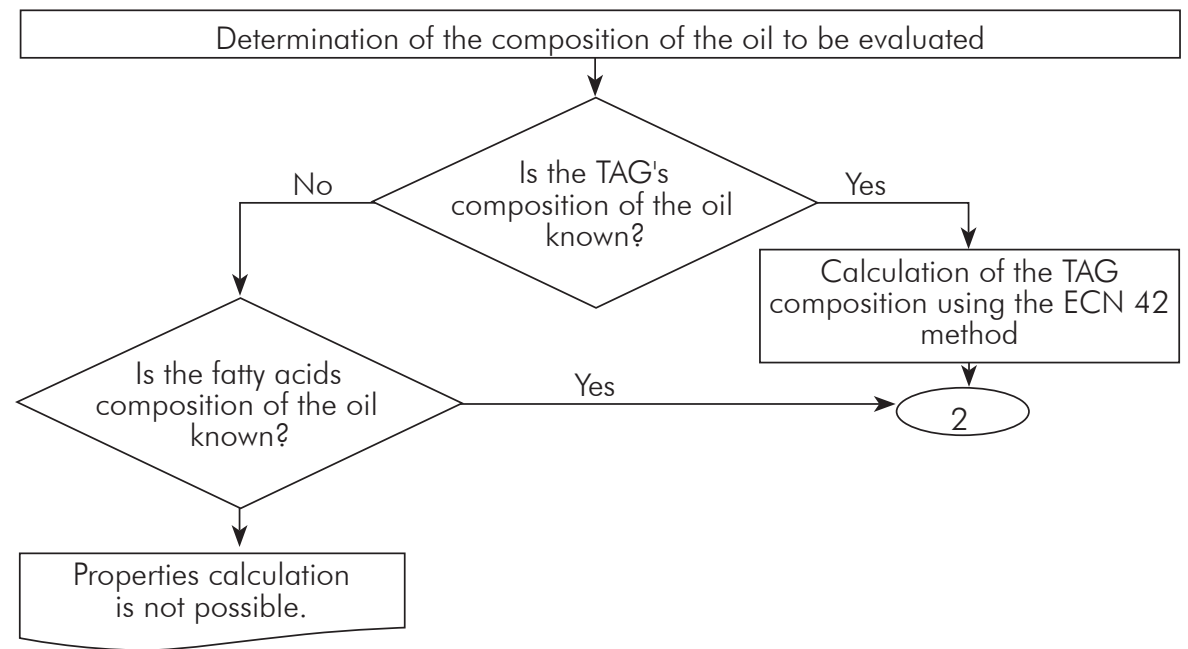

Figure 3. Flowchart used for data entry to the OIL-CALPROP, VERSION 1.0 Software.

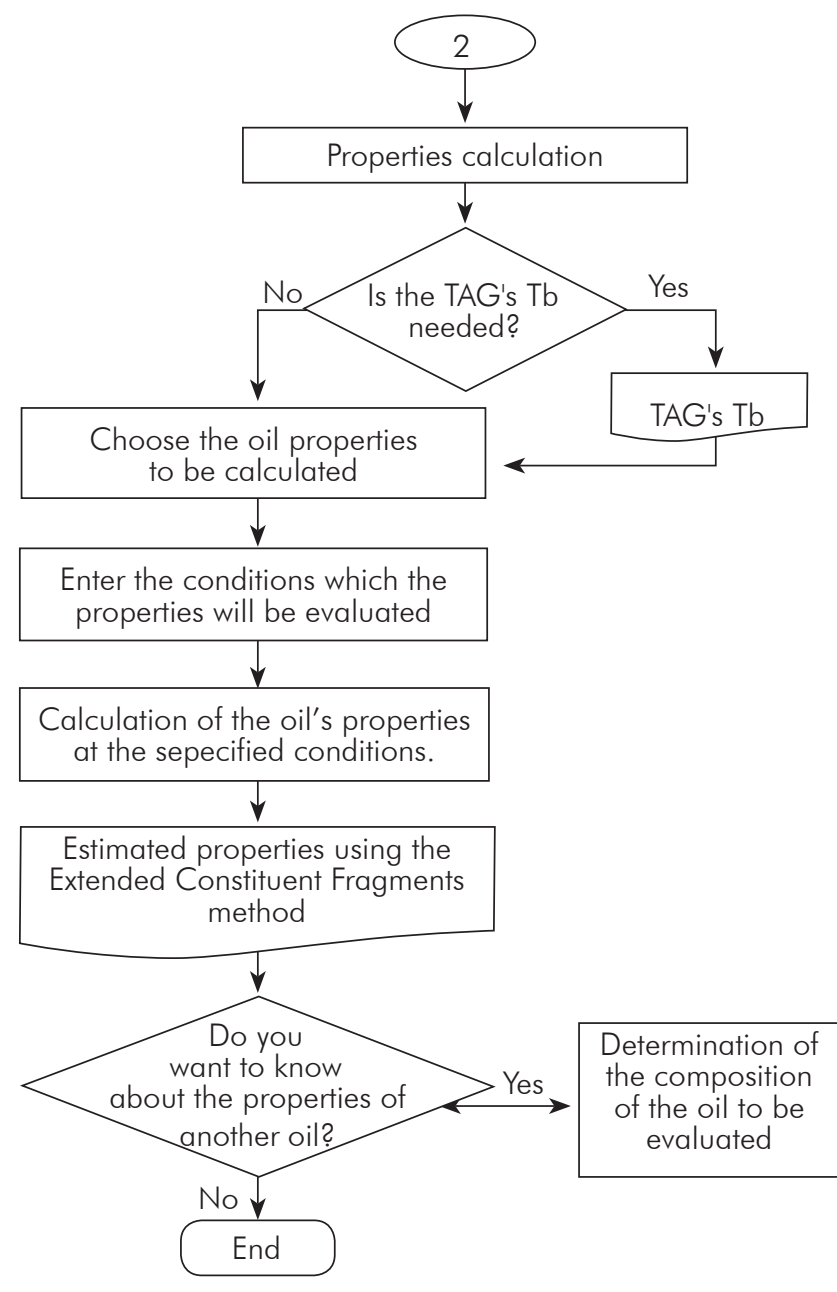

Figure 4. Flowchart for determination of properties of oils using the Extended Constituent Fragments method.
Table 1. Soybean oil fatty acid profile used by the OIL-CALPROP software for the calculation of thermophysical properties (Park, Chang \& Lee, 2010).

\begin{tabular}{|c|ccc|}
\hline Fatty Acid & \# of Carbons & Fatty Acid (\%) & $\begin{array}{c}\text { Molecular } \\
\text { Weight }\end{array}$ \\
\hline Palmitic & C 16:0 & 11.3 & 256.43 \\
\hline Oleic & C 18:1 n-9 & 23 & 282.5 \\
\hline Linoleic & C 18:2 n-6 & 53.4 & 280.4 \\
\hline Linolenic & C 18:3 n-3 & 5.96 & 278.4 \\
\hline
\end{tabular}

\section{Calculation of TAG's' Thermophysical Properties} Using the ECF Method

Unlike the CF method proposed by Zong et al. (2010a) the ECF methodology proposed here considers TAG's as molecules formed by fragments of not necessarily equal fatty acids and glycerol (Figure 5).

In addition, the adjustment parameters of the equations in Table 2 were recalculated, using, in some cases, more recent experimental values than those employed by Zong et al. (2010a).

\section{Boiling Temperature}

In addition to extending the CF methodology, this work employs the semi-empirical approach proposed 


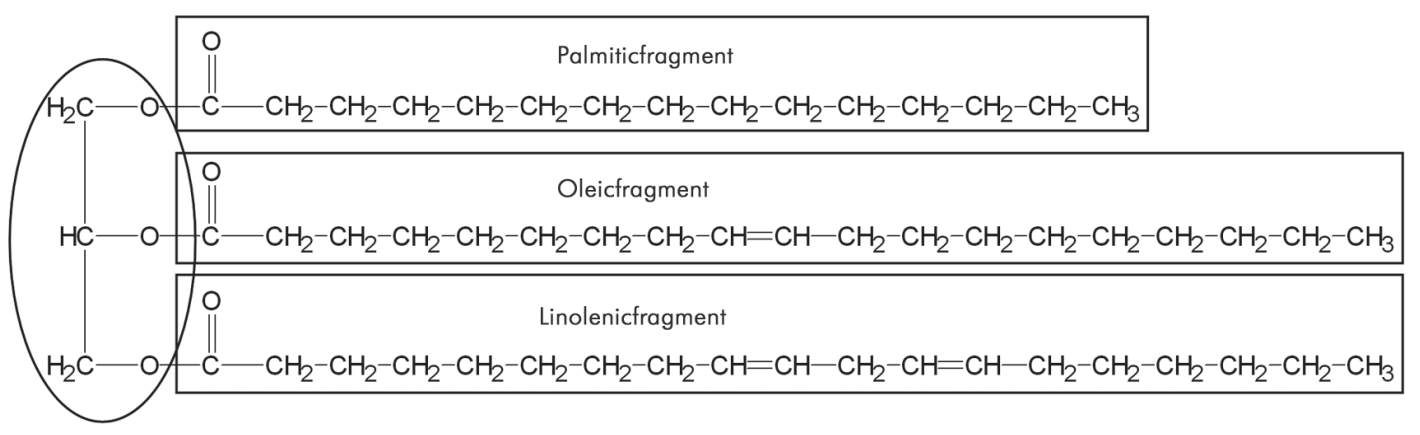

Glicerolfragment

Figure 5. Fragments' characterization of a heterogeneous triglyceride, adapted from Zong et al. (2010a).

Table 2. Equations for the calculation of TAG's thermophysical properties.

\begin{tabular}{|c|c|c|c|c|c|}
\hline Property & Expression for Calculating Fragment Contrib & Jtion & Method Expression & & References \\
\hline Vapor Pressure & $\begin{array}{c}\log P(T)=A-\frac{B}{T}=\frac{-\Delta G_{\theta}^{\text {vap }}}{R \theta \ln 10}+\frac{\Delta H_{\theta}^{\text {vap }}}{R \ln 10}\left(\frac{1}{\theta}-\frac{1}{T}\right) \\
\text { Clausius - Clapeyron Equation }\end{array}$ & (1) & $\begin{aligned} \Delta H_{\theta}^{v a p} & =\sum N_{f r a g, A} \Delta H_{\theta, A}^{v a p} \\
\Delta G_{\theta}^{v a p} & =\sum N_{f r a g, A} \Delta G_{\theta, A}^{v a p}\end{aligned}$ & $\begin{array}{l}\text { (2) } \\
\text { (3) }\end{array}$ & $\begin{array}{l}\text { Perry, Webwe \& } \\
\text { Daubert, } 1949 .\end{array}$ \\
\hline $\begin{array}{l}\text { Calorific } \\
\text { Capacity }\end{array}$ & $C_{p}^{l}=\sum_{A} N_{f r a g, A} C_{p, A}^{l}(T)$ & (4) & $C_{P, A}^{l}=A_{1, A} T+A_{2, A}$ & (5) & $\begin{array}{l}\text { Morad, Mustafa, } \\
\text { Panau \& Yew, } \\
2000 .\end{array}$ \\
\hline $\begin{array}{l}\text { Density and } \\
\text { Specific Molar } \\
\text { Volume }\end{array}$ & $\begin{array}{c}\qquad V_{A}^{l}=\frac{1+B_{2, A} T}{B_{1, A}} \\
\text { Van Krevelen Equation }\end{array}$ & (6) & $V^{l}=\sum_{A} N_{f r a g, A} V_{A}^{l}(T)$ & (7) & $\begin{array}{l}\text { Phillips \& } \\
\text { Mattamal, 1978; } \\
\text { Noureddini, Teoh } \\
\text { \& Clements, } \\
\text { 1992a. }\end{array}$ \\
\hline Viscosity & $\ln \eta^{l}=\sum_{A} N_{\text {frag }, A} \ln \eta_{A}^{l}(T)$ & (8) & $\ln \eta_{A}^{l}=C_{1, A}+\frac{C_{2, A}}{T}+\ln (T)$ & (9) & $\begin{array}{c}\text { Noureddini, Teoh } \\
\text { \& Clements, } \\
\text { 1992b; } \\
\text { Rodríguez, Galan, } \\
\text { Muñoz \& Martin, } \\
\text { 1994; Niir, 2002; } \\
\text { Ceriani et al., } \\
2007 .\end{array}$ \\
\hline
\end{tabular}

by Zong et al. (2010a) to propose, for the first time, a strategy that allows for the calculation of the TAG's boiling temperature based on their constituent fragments.

For this purpose, a relationship is proposed between the boiling temperature values of each of the TAG's fragments (acids and glycerol) and the pressure at which this property is measured. Initially, the experimental data (Niir, 2002) on the temperature of each of the fragments were adjusted to Equation 10:
$T_{a}^{b}=a \times \ln (P)+b$

Where $a$ and $b$ are the adjustment parameters of each fragment, $T_{a} b$ is the boiling temperature of the fragment $a(\mathrm{~K})$ and $P$ the pressure $(\mathrm{mmHg})$.

Knowing the $T_{a}^{b}$ for each one of the fragments, it is possible to calculate the TAG's $T b$ value using Equation 11.

$$
T_{\text {TAG }}^{b}=\frac{\sum N_{\text {Frag, }, a} * T_{a}^{b}}{3}
$$


Table 3. Equations for calculation of the properties of oils.

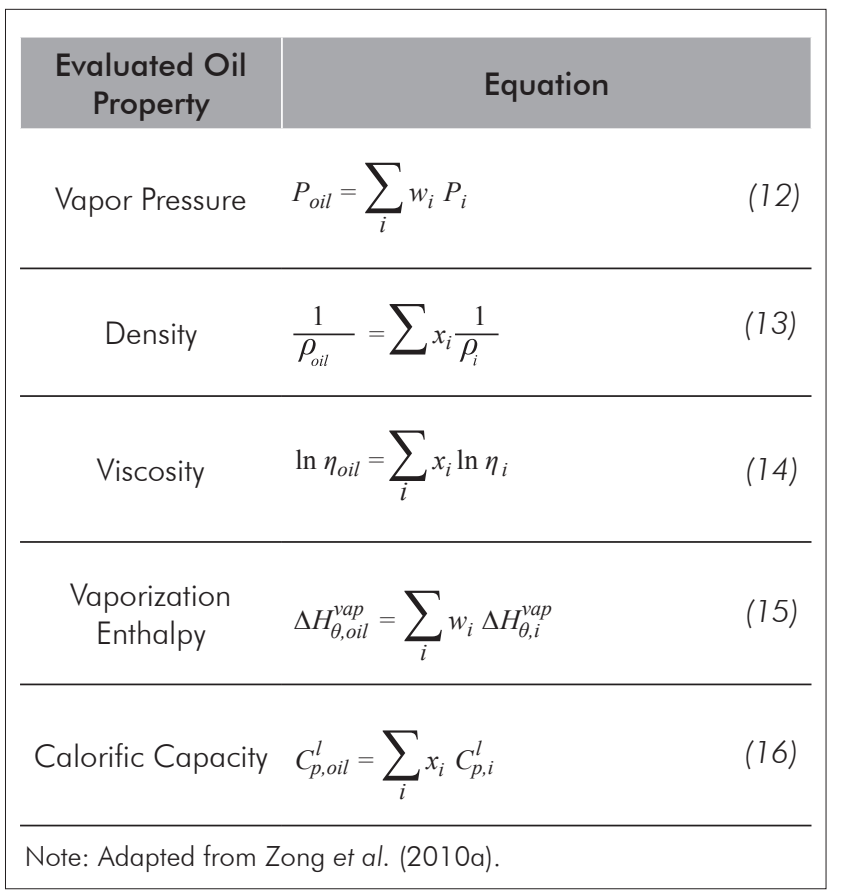

Where, $T_{T A G}^{b}$ is the boiling temperature of the TAG (K) and $N_{F r a g}$ is the number of fragments $a$.

\section{Calculation of the Thermophysical Properties of Oils}

Oils are characterized by a mixture of fatty acids, monoglycerides, diglycerides, triglycerides and minor constituents (carotenes, sterols, etc.). However, TAG's constitute the more representative portion of the mix (75-98\% by weight) (Gunstone, 2004). Therefore, for the calculation of their properties, it will be assumed that the oil is formed exclusively by triglycerides. The relationships used for calculating each of the considered properties are listed in Table 3.

\section{RESULTS}

\section{Adjusted Equation Parameter}

Table 4 shows the adjusted values of each of the parameters that will be used for the calculation of thermophysical properties using the ECF method. In this table

Table 4. Adjusted parameters for Equations 1 - 11.

\begin{tabular}{|c|c|c|c|c|c|c|c|c|c|c|c|}
\hline \multirow[b]{2}{*}{$\begin{array}{c}\text { Setting } \\
\text { parameters }\end{array}$} & \multicolumn{2}{|c|}{ Vapor Pressure } & \multicolumn{2}{|c|}{ Calorific Capacity } & \multicolumn{2}{|c|}{ Density } & \multicolumn{2}{|c|}{ Boiling Temperature } & \multicolumn{3}{|c|}{ Viscosity } \\
\hline & $\begin{array}{c}\Delta \mathrm{H}_{\theta}^{\text {vap }} \\
(\mathrm{J} / \mathrm{kmol})\end{array}$ & $\begin{array}{c}\Delta \mathrm{G}^{\text {vap }} \\
(\mathrm{J} / \mathrm{kmol})\end{array}$ & $\begin{array}{c}\mathrm{A}_{1 . \mathrm{A}} \\
(\mathrm{J} / \mathrm{kmol} \cdot \mathrm{K})\end{array}$ & $\begin{array}{c}\mathrm{A}_{2 . \mathrm{A}} \\
\left(\mathrm{J} / \mathrm{kmol}^{\left.-\mathrm{K}^{2}\right)}\right.\end{array}$ & $\begin{array}{c}\mathrm{B}_{1 . \mathrm{A}} \\
\left(\mathrm{kmol} / \mathrm{m}^{3}\right)\end{array}$ & $\begin{array}{l}\mathrm{B}_{2 . \mathrm{A}} \\
\left(\mathrm{K}^{-1}\right)\end{array}$ & a & b & $\mathrm{C}_{1 . \mathrm{A}}(\mathrm{Pa} \cdot \mathrm{s})$ & $\mathrm{C}_{2 . \mathrm{A}}(\mathrm{K})$ & $\mathrm{C}_{3 . \mathrm{A}}(\mathrm{K})$ \\
\hline Glycerol & $-3.48 \mathrm{E}+07$ & $-6.27 E+07$ & $1.48 \mathrm{E}+02$ & $6.14 \mathrm{E}+04$ & $2.00 E+01$ & 7.69E-04 & $1.77 \mathrm{E}+01$ & $4.46 \mathrm{E}+02$ & $9.65 \mathrm{E}+01$ & $-3.01 E+03$ & $-5.74 \mathrm{E}+01$ \\
\hline Butyric acid & $3.89 E+07$ & $2.43 \mathrm{E}+07$ & $1.87 \mathrm{E}+02$ & $9.88 \mathrm{E}+04$ & $2.08 \mathrm{E}-02$ & 2.01E-03 & $\mathrm{NE}$ & $\mathrm{NE}$ & $-5.10 E+01$ & $2.55 \mathrm{E}+03$ & $2.13 E+01$ \\
\hline $\begin{array}{c}\text { Caproic } \\
\text { acid }\end{array}$ & $4.33 \mathrm{E}+07$ & $2.79 E+07$ & $2.30 E+02$ & $1.43 E+05$ & $1.41 \mathrm{E}-02$ & $1.54 \mathrm{E}-03$ & $2.15 \mathrm{E}+01$ & $3.26 \mathrm{E}+02$ & $-5.19 E+01$ & $2.63 E+03$ & $2.14 \mathrm{E}+01$ \\
\hline $\begin{array}{c}\text { Caprylic } \\
\text { acid }\end{array}$ & $5.01 \mathrm{E}+07$ & $3.24 \mathrm{E}+07$ & $3.41 E+02$ & $1.68 \mathrm{E}+05$ & 1.30E-02 & $1.42 \mathrm{E}-03$ & $2.28 \mathrm{E}+01$ & $3.51 E+02$ & $-5.51 E+01$ & $2.87 E+03$ & $2.18 \mathrm{E}+01$ \\
\hline Capric acid & $5.37 \mathrm{E}+07$ & $3.56 \mathrm{E}+07$ & $4.53 \mathrm{E}+02$ & $1.97 E+02$ & 1.30E-02 & $1.42 \mathrm{E}-03$ & $2.38 \mathrm{E}+01$ & $3.73 E+02$ & $-5.48 E+01$ & $2.92 \mathrm{E}+03$ & $2.18 \mathrm{E}+01$ \\
\hline Lauric acid & $5.77 \mathrm{E}+07$ & $3.89 \mathrm{E}+07$ & $4.44 \mathrm{E}+02$ & $2.53 E+05$ & 1.27E-02 & 1.39E-03 & $2.51 E+01$ & $3.92 \mathrm{E}+02$ & $-5.66 \mathrm{E}+01$ & $3.06 \mathrm{E}+03$ & $2.20 \mathrm{E}+01$ \\
\hline Myristic acid & $6.08 \mathrm{E}+07$ & $4.18 \mathrm{E}+07$ & $4.57 \mathrm{E}+02$ & $3.19 E+05$ & $5.76 \mathrm{E}-03$ & 1.32E-03 & $2.63 \mathrm{E}+01$ & $4.10 E+02$ & $-5.93 E+01$ & $3.26 \mathrm{E}+03$ & $2.24 \mathrm{E}+01$ \\
\hline Palmitic acid & $6.53 \mathrm{E}+07$ & $4.50 \mathrm{E}+07$ & $7.99 \mathrm{E}+02$ & $2.80 \mathrm{E}+05$ & $5.02 \mathrm{E}-03$ & $1.28 \mathrm{E}-03$ & $2.73 E+01$ & $4.27 \mathrm{E}+02$ & $-6.03 E+01$ & $3.34 \mathrm{E}+03$ & $2.26 \mathrm{E}+01$ \\
\hline $\begin{array}{l}\text { Palmitoleic } \\
\text { acid }\end{array}$ & NE & NE & NE & NE & $\mathrm{NE}$ & $\mathrm{NE}$ & $\mathrm{NE}$ & $\mathrm{NE}$ & $-6.03 E+01$ & $3.34 \mathrm{E}+03$ & $2.26 \mathrm{E}+01$ \\
\hline Stearic acid & $6.73 \mathrm{E}+07$ & $4.67 \mathrm{E}+07$ & $4.81 \mathrm{E}+02$ & $4.69 E+05$ & $4.46 \mathrm{E}-03$ & $1.26 \mathrm{E}-03$ & $2.85 E+01$ & $4.43 E+02$ & $-6.73 E+01$ & $3.81 E+03$ & $2.35 E+01$ \\
\hline Oleic acid & $6.73 E+07$ & $4.67 \mathrm{E}+07$ & $5.41 \mathrm{E}+02$ & $3.98 \mathrm{E}+05$ & NE & $\mathrm{NE}$ & $\mathrm{NE}$ & NE & $-5.38 \mathrm{E}+01$ & $2.91 \mathrm{E}+03$ & $2.17 \mathrm{E}+01$ \\
\hline Linoleic acid & NE & NE & NE & $\mathrm{NE}$ & $\mathrm{NE}$ & $\mathrm{NE}$ & $\mathrm{NE}$ & $\mathrm{NE}$ & $-3.93 E+01$ & $2.22 \mathrm{E}+03$ & $1.95 E+01$ \\
\hline $\begin{array}{l}\text { Linolenic } \\
\text { acid }\end{array}$ & NE & NE & NE & NE & NE & NE & NE & NE & $-2.88 E+01$ & $1.49 E+03$ & $1.80 \mathrm{E}+01$ \\
\hline $\begin{array}{l}\text { Arachidic } \\
\text { acid }\end{array}$ & NE & NE & NE & NE & NE & NE & NE & NE & $-6.62 E+01$ & $3.79 E+03$ & $2.34 \mathrm{E}+01$ \\
\hline Behenic acid & $\mathrm{NE}$ & $\mathrm{NE}$ & $\mathrm{NE}$ & $\mathrm{NE}$ & $\mathrm{NE}$ & $\mathrm{NE}$ & $\mathrm{NE}$ & $\mathrm{NE}$ & $-6.82 E+01$ & $3.95 \mathrm{E}+03$ & $2.37 E+01$ \\
\hline Erucic acid & NE & $\mathrm{NE}$ & $\mathrm{NE}$ & $\mathrm{NE}$ & $\mathrm{NE}$ & $\mathrm{NE}$ & $\mathrm{NE}$ & $\mathrm{NE}$ & $-6.82 E+01$ & $3.95 \mathrm{E}+03$ & $2.37 E+01$ \\
\hline
\end{tabular}


all adjustable parameters, with exception of density, were determinate employing a linear function which considerate to carbon number of fragment as independent variable.

\section{Evaluation of the Accuracy Degree of the Predicted Thermophysical Properties of Soybean Oil}

Table 5 shows the results of the TAG's composition profile predicted by the ECN 42 method, which will be used for the calculation of the thermophysical properties of soybean oil. When the predicted composition values are compared with the available experimental data, it can be seen that the predictive method has relative estimation errors of less than $7 \%$ for three out of the five compared TAG's.

The degree of prediction of each thermophysical property evaluated using the HYSYS ${ }^{\circledR}$ Simulator, the $\mathrm{CF}$ method and the method proposed here are shown in Figures 6 to 9. In the case of the ECF method, results were obtained using the OIL-CALPROP (version 1.0) software and unless otherwise stated, these were calculated from the fatty acid profile.

\section{Vapor Pressure}

The results in Figure 6 clearly show that the ECF method improves the predictive capacity of the soybean oil vapor pressure. This result was expected,
Table 5. TAG composition for soybean oil obtained using the ECN 42 method on the fatty acid profile of soybean oil.

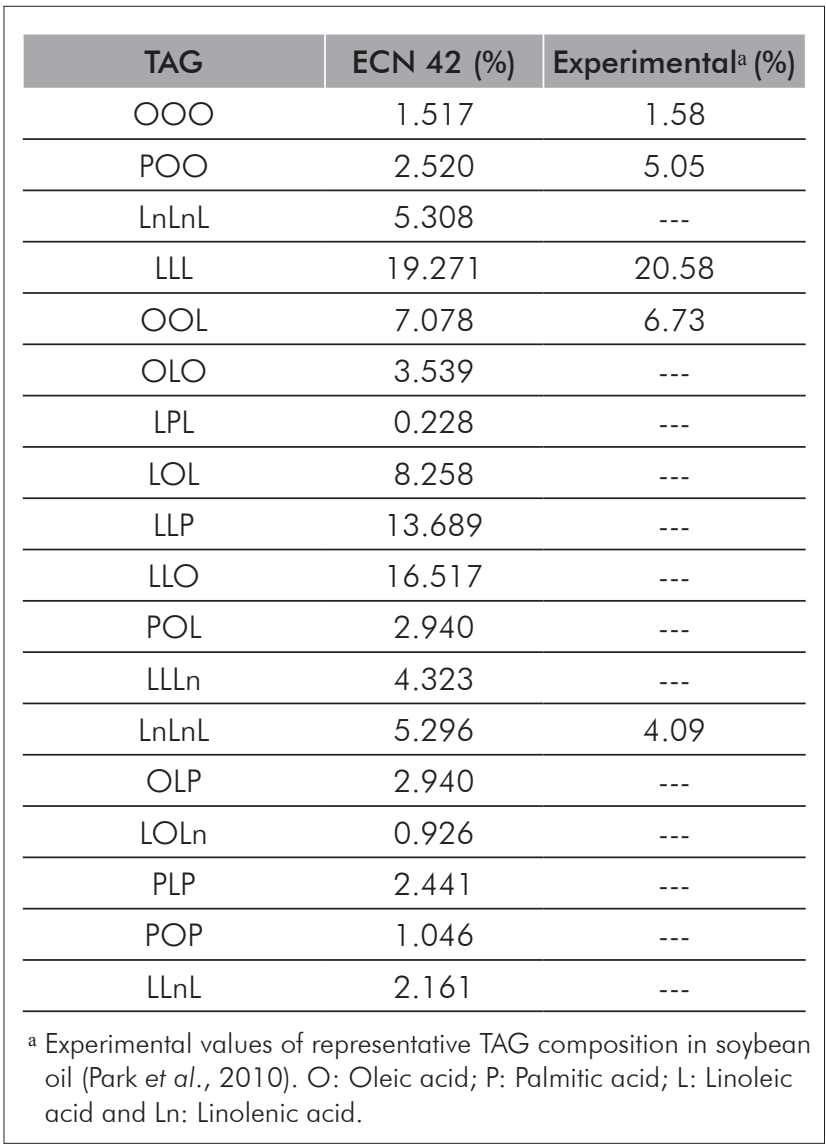

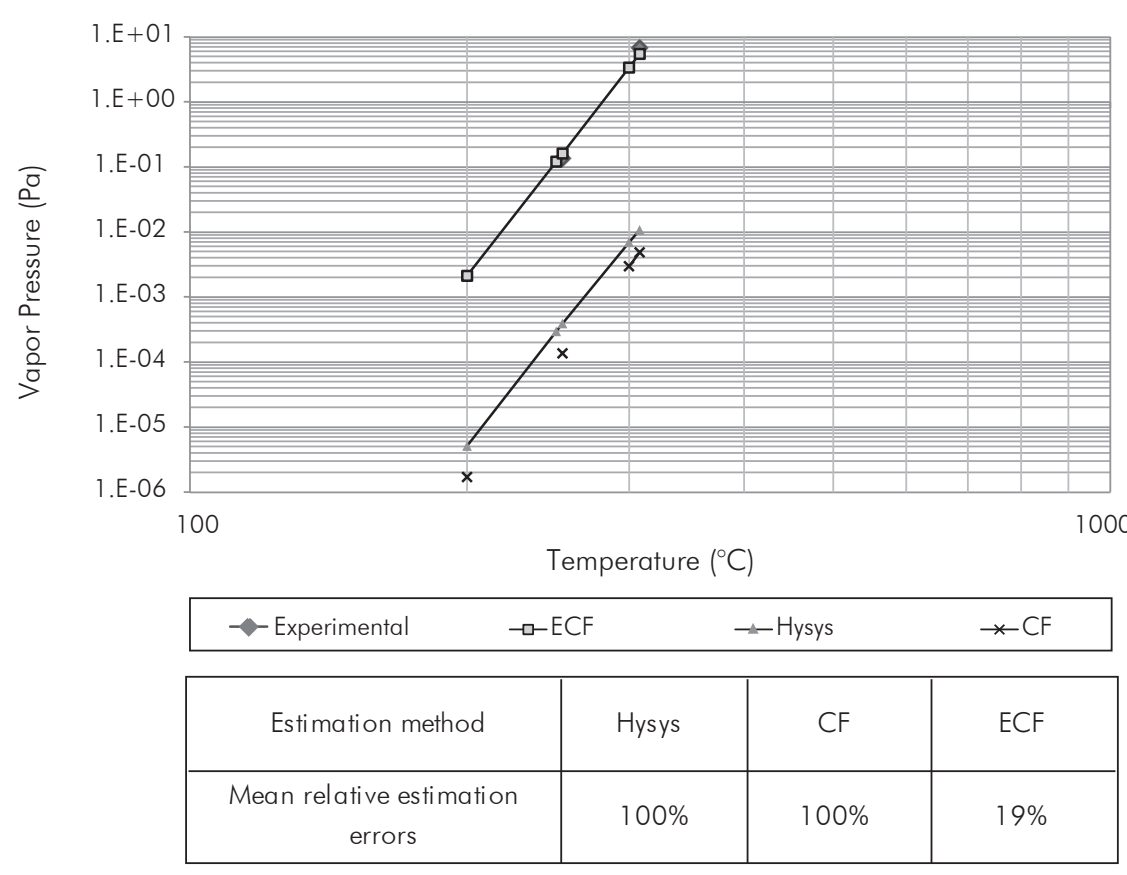

Figure 6. Vapor pressure of soybean oil. 
since the ECF method considers a greater number of TAG's than the CF method and consequently the profile is closer to the oils' characteristics. Generally, the ECF method leads to an average relative error of $19 \pm 1.5 \%$, whereas the use of HYSYS (PengRobinson) or the CF method results in mean relative errors that are close to $100 \pm 0.029 \%$. In addition, the vapor pressure values predicted by these two last methods are underestimated by up to 3 orders of magnitude (Figure 6).

\section{Calorific Capacity}

As in the previous case, the results obtained by the ECF method have a higher degree of accuracy than those obtained by the other two methods (Figure 7). In this particular case the mean relative error obtained with the ECF method is only $15 \pm 0.019 \%$, while for the CF method and HYSYS ${ }^{\circledR}$ (Peng-Robinson) these errors were $37 \pm 0.022$ and $93 \pm 0.005 \%$, respectively. The reason for this behavior is probably that the ECF method considers that a greater number of TAG's constitute the oil, consequently improving the approximation of the simulated matrix. In addition, when the experimental TAG profile of soybean oil (Cunha \& Oliveira, 2006) is considered for the calculation of calorific capacity, the average relative error is $\sim 14 \%$.

\section{Density}

As shown in Figure 8, the results obtained with the ECF and CF methods are equivalent and in both cases predict the density value with high accuracy (mean relative errors between $1.4 \pm 0.42$ and $3 \pm 0.25 \%$ ). In the case of the values predicted by HYSYS ${ }^{\circledR}$, they lack physical significance for all the assessed range, a result associated with the initial assumption that triolein is the oil's only constituent. In addition, the predictive capacity of the ECF method was evaluated when starting with the experimental TAG profile determined by Cunha and Oliveira (2006) and the mean relative error obtained was $\sim 3 \%$.

\section{Viscosity}

The predictive accuracy of each one of the methods used for the calculation of the viscosity of soybean oil is shown in Figure 9.

The figure shows that both constituent fragments methods, either with and without modifications, have the best predictive accuracy for this property. However, the best adjustment level is obtained using the unaltered constituent fragments method, which produces a mean relative error of $10 \pm 8 \% v r$. the 20 $\pm 7 \%$ obtained when using the ECF method. This unexpected behavior may be associated with the pre-

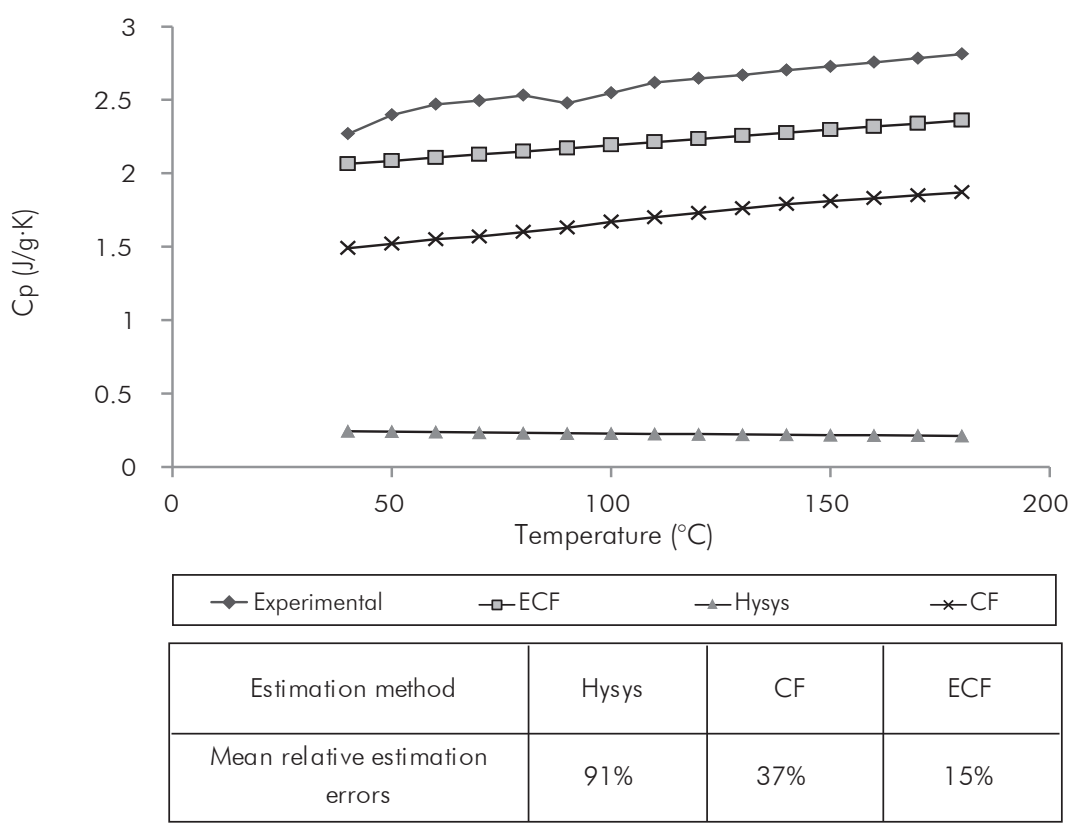

Figure 7. Calorific capacity of soybean oil. 


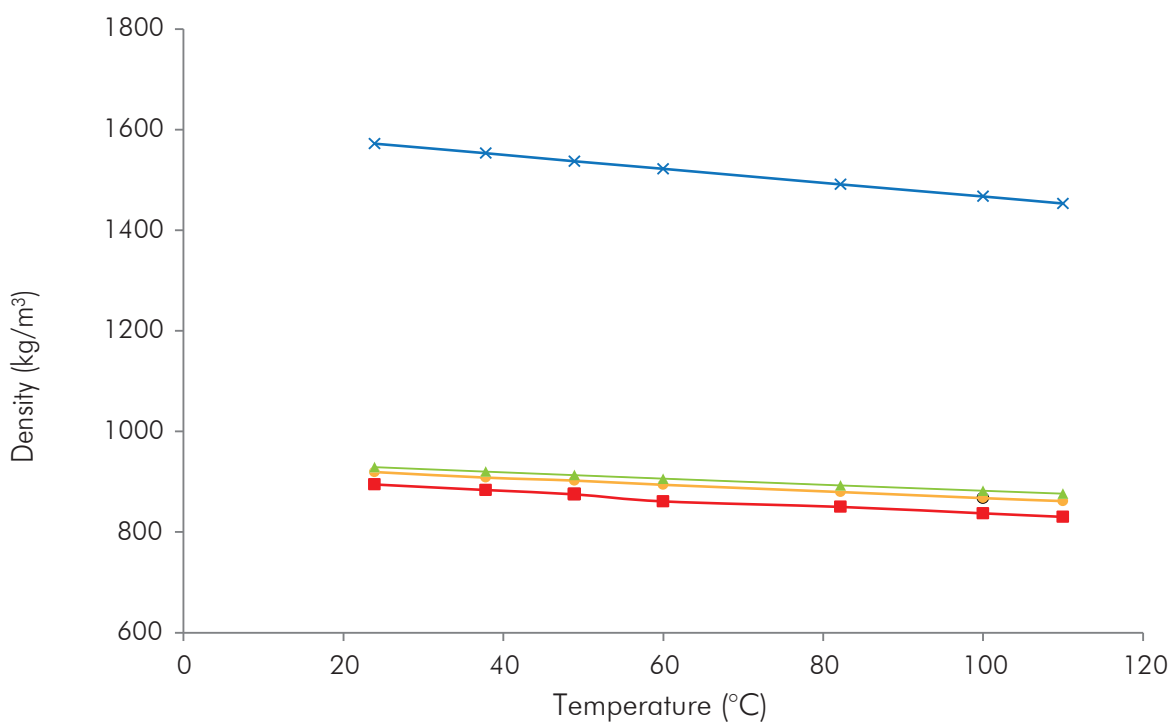

\begin{tabular}{|c|c|c|c|}
\hline$\rightarrow$ Experimental & - ECF & $\rightarrow$ CF & $*$ Hysys \\
\hline Estimation method & Hysys & CF & ECF \\
\hline $\begin{array}{c}\text { Mean relative estimation } \\
\text { errors }\end{array}$ & $70 \%$ & $1.4 \%$ & $3 \%$ \\
\hline
\end{tabular}

Figure 8. Soybean oil density.

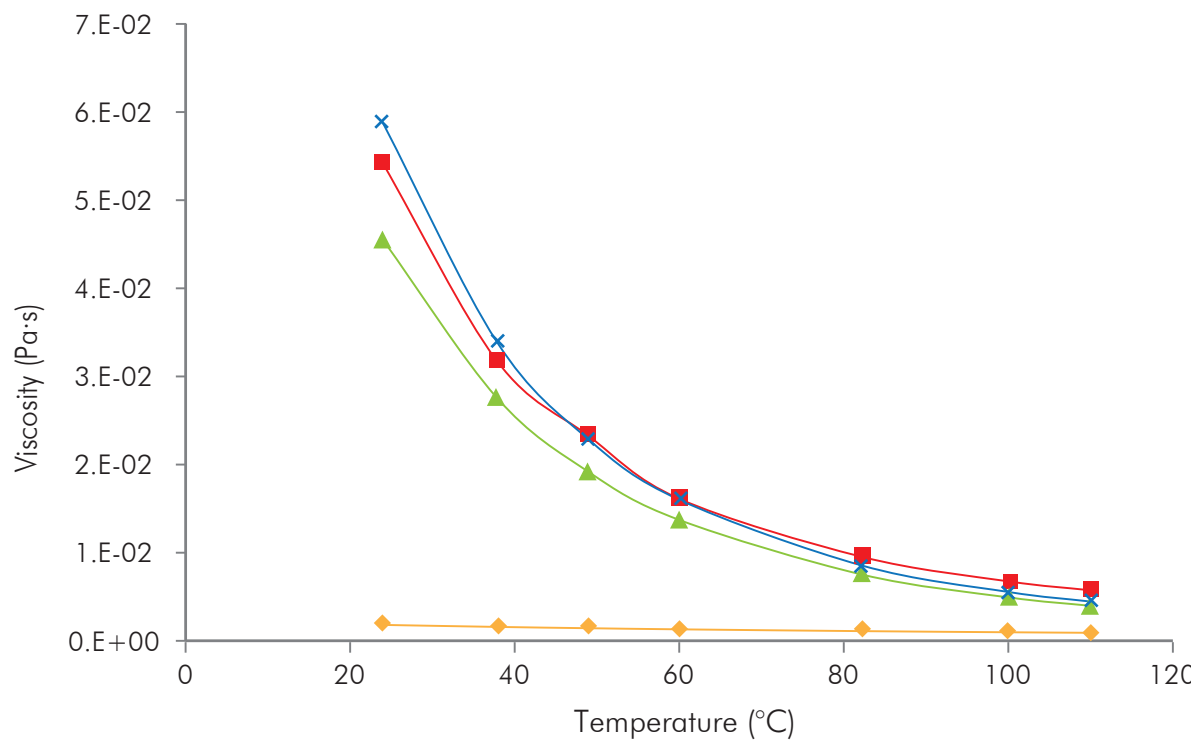

\begin{tabular}{|c|c|c|c|}
\hline$\rightarrow$ Hysys & $\rightarrow$ Experimental & $\rightarrow$ EFC & $*$ CF \\
\hline Estimation method & Hysys & ECF \\
\hline $\begin{array}{c}\text { Mean relative estimation } \\
\text { errors }\end{array}$ & $91 \%$ & $10 \%$ & $20 \%$ \\
\hline
\end{tabular}

Figure 9. Viscosity of soybean oil. 
dictive errors of the TAG profile calculated using the ECN 42 method.

Consequently, the property value was recalculated using a triglyceride experimental profile of soybean oil (Cunha \& Oliveira, 2006). The mean relative error obtained using the ECF method after using the experimental TAG's profile was reduced from $20 \pm 7$ to $9 \pm 3 \%$.

\section{Boiling Temperature}

The results obtained for the $T_{T A G}^{b}$ are shown in Table 6.

Table 6. Comparison of normal boiling temperatures of homogeneous TAG's.

\begin{tabular}{|c|c|cc|}
\hline Triglyceride & $\begin{array}{c}\text { ECF } \\
(\mathrm{K})\end{array}$ & $\begin{array}{c}\text { Experimental } \\
(\mathrm{K})\end{array}$ & $\begin{array}{c}\text { Error } \\
(\%)\end{array}$ \\
\hline Tricaproin & 666.67 & 646.43 & 3.04 \\
\hline Tricaprylin & 700.57 & 657.76 & 6.11 \\
\hline Tricaprin & 730.87 & 667.1 & 8.72 \\
\hline Trilaurin & 759.77 & 680.9 & 10.38 \\
\hline Trimyristin & 787.07 & 663.15 & 15.74 \\
\hline Tripalmitin & 812.37 & 675.03 & 16.91 \\
\hline Tristearin & 836.97 & 682.65 & 18.44 \\
\hline
\end{tabular}

A direct relationship between error values and the number of carbons in the TAG is observed when the results obtained by this method are compared with experimental data, suggesting that calculations can be corrected. The following expressions are obtained using a graph of the error values against the number of carbons in the TAG's:

Boiling temperature at $760 \mathrm{mmHg}$ :

$T_{T A G}^{b}=(1-(0.0045 * \# C-0.0603)) * \frac{\sum N_{\text {Frag, } a} T_{a}^{b}}{3}$

For pressures lower than $760 \mathrm{mmHg}$ :

$T_{T A G}^{b}=(1-(d * \# C+e)) * \frac{\sum N_{\text {Frag, } a} T_{a}^{b}}{3}$

Where, $d$ and $e$ are pressure-dependent setting parameters $\mathrm{P}[\mathrm{mmHg}]$ and $\# \mathrm{C}$ is the number of carbons in the TAG:

$d=1.082 * 10^{-5}(P)-0.003725$ $e=0.1592-1.301 * 10^{-4}(P)$

In this way, knowing the number of carbons of a triglyceride and the pressure at which boiling temperature is required is enough to calculate it.

While there are few data for comparison (see Table 7), the proposed correlation can estimate the boiling temperature with mean relative errors close to $1 \%$. In addition, these new approach have a close relation with additive relation of Gibbs which has been employed previously for predicts thermophysical properties (Zong et al., 2010a-2010b).

On the other hand, using the only TAG in the Aspen HYSYS ${ }^{\circledR}$ database the relative error obtained is $29 \%$. In addition, the proposed expression can be applicable for the calculation of heterogeneous TAG's Tb when experimental data are not available. However, Equations 17 and 18 are limited to the values of the adjusted fragments (see Table 4).

\section{DISCUSSION}

In general, it can be seen that the results obtained by the ECF method have smaller estimation errors than those obtained using the commercial Aspen HYSYS simulation tool and the CF method. While the mean relative errors obtained when using the ECF method are between $1-20 \%$ those obtained using HYSYS $\AA$ and CF varied between $70-100$ and $1.4-100 \%$, respectively, depending on the calculated property. For example, the ECF method was superior to the CF method in calculating the thermodynamic properties, regardless of whether the latter are calculated from the fatty acids' or TAG's profiles. This seems to indicate that thermodynamic properties (heat capacity and vapor pressure) are less sensitive to inaccuracies in the TAG profile than transport properties. On the other hand, in the case of viscosity, the mean relative error obtained by the ECF method when using the fatty acids profile was greater than the calculated error when the starting point is the TAG's profile (20\% from fatty acids vs. $9 \%$ from TAG's). Consequently, it can be inferred that the ECF method has a greater predictive capacity than its predecessor (CF) and that this capacity depends on the degree of confidence or knowledge of the characterized lipid matrix. 
Table 7. Normal boiling temperatures of TAG's.

\begin{tabular}{|c|c|c|c|c|c|}
\hline \multirow[b]{2}{*}{ TAG } & \multicolumn{5}{|c|}{ TAG Boiling Temperature (760 mmHg) } \\
\hline & Experimental DSCa $(\mathrm{K})$ & Fragments (K) & Hysys (K) & Fragments Error (\%) & Hysys Error (\%) \\
\hline LLL & 682.65 & 672.75 & --- & 1.45 & --- \\
\hline PPP & 675.03 & 674.91 & -- & 0.02 & --- \\
\hline 000 & 682.65 & 672.75 & 879.65 & 1.45 & 28.86 \\
\hline LnLO & --- & 672.75 & --- & --- & --- \\
\hline $\mathrm{LLO}$ & -- & 672.75 & -- & --- & -- \\
\hline $\mathrm{LnOO}$ & --- & 672.75 & --- & --- & --- \\
\hline $\mathrm{LnOP}$ & --- & 673.62 & --- & --- & -- \\
\hline LOO & --- & 672.75 & --- & --- & --- \\
\hline $\mathrm{POO}$ & --- & 673.62 & --- & --- & --- \\
\hline LLP & --- & 673.62 & --- & --- & --- \\
\hline $\operatorname{LnLL}$ & --- & 672.75 & --- & --- & --- \\
\hline $\operatorname{Ln} \operatorname{LnO}$ & --- & 672.75 & --- & --- & --- \\
\hline \multirow[t]{2}{*}{ LOP } & --- & 673.62 & --- & --- & --- \\
\hline & \multicolumn{2}{|c|}{ Mean relative error } & & 0.97 & 28.86 \\
\hline
\end{tabular}

These results were expected, since the ECF method considers the oil as a mixture of TAG's, both homogeneous and heterogeneous, while estimates of thermodynamic properties for vegetable oils using $\mathrm{CF}$ and Aspen HYSYS ${ }^{\circledR}$ are performed under the assumption that only homogenous TAG's constitute the oil (Martinho et al., 2008).

Although the commonly used approach to simulate processes involving oils as raw material has been to consider them as triolein, the method validated in this work emerges as a viable and simple solution to improve the results of these simulations.

If this option is considered, the problems associated with the definition of new triglycerides in Aspen HYSYS ${ }^{\circledR}$ (Santana et al., 2010) are solved.

Regarding the calculation of boiling temperatures, the proposed correlation based on the Constituent Fragments methodology is capable of estimating TAG's boiling temperatures with mean relative errors close to $1 \%$, whereas for the only TAG present in the Aspen HYSYS ${ }^{\circledR}$ database the relative error is $\sim 29 \%$. In addition, this correlation can be easily applicable in the calculation of boiling temperatures of heterogeneous TAG's where no experimental data is available.

\section{CONCLUSIONS}

- From the results obtained in this work it is concluded that the introduction of a routine that allows for estimating the triglyceride (both homogeneous and heterogeneous) composition of oils improves the accuracy level of the predictions of thermodynamic properties. For example, when the ECF method is compared with the CF method, the average relative errors in the prediction of calorific capacity and vapor pressure are reduced in 22 and $81 \%$, respectively. Furthermore, the inclusion of such prediction routine makes the ECF method more flexible than the CF method, since in the specialized literature the characterization of oils in terms of fatty acids profiles is more common than their characterization in TAG profiles.

- Regarding the prediction of transport properties (viscosity and density) the ECF and CF methods are 
equivalent if the starting point for the prediction of the properties is the TAG's profile.

- In addition, the methodology proposed in this paper provides a new tool for calculation of triglycerides' boiling temperatures. In these regard, the results show that predictive errors do not exceed $1 \%$.

- In general, it can be observed that the maximum error obtained by the ECF method is $20 \%$ (percentage obtained in oil viscosity calculations).

\section{ACKNOWLEDGEMENTS}

The authors are grateful to Vicerrectoria de Investigación y Extensión of the Universidad Industrial de Santander for its financial support throughout project number 5452.

\section{REFERENCES}

Anitescu, G. \& Bruno, T. (2012). Fluid properties needed in supercritical transesterification of triglyceride feedstocks to biodiesel fuels for efficient and clean combustion - A review. J. of Supercritical Fluids, 63: 133-149.

Ceriani, R., Gonçalves, C. B., Rabelo, J., Caruso, M., Cunha, A. C. C., Cavaleri, F. W., Batista, E. A. C. \& Meirelles A. J. A. (2007). Group contribution model for predicting viscosity of fatty compounds. J. Chem. Eng. Data, 52(3), 965-972.

Chisti, Y. (2007). Biodiesel from microalgae. Biotechnol. Adv., 25(3), 294-306.

Cunha, S. \& Oliveira, M. B. P. P. (2006). Discrimination of vegetable oils by triacylglycerols evaluation of profile using HPLC/ELSD. Food Chem., 95(3), 518-524.

Díaz-Tovar, C., Gani, R. \& Sarup, B. (2011). Lipid technology: Property prediction and process design/analysis in the edible oil and biodiesel industries. Fluid Phase Equilibria, 302(1-2), 284-293.

Goodrum, J. W. \& Geller, D. P. (2002). Rapid thermogravimetric measurements of boiling points and vapor pres- sure of saturated medium-and long-chain triglycerides. Bioresource Technol., 84(1), 75-80.

Gunstone, F. (2004). The chemistry of oils and fats sources, composition, properties and uses. Australia: Blackwell Pusblishing.

Lee, S., Posarac, D. \& Ellis, N. (2011). Process simulation and economic analysis of biodiesel production processes using fresh and waste vegetable oil and supercritical methanol. Chem. Eng. Research and Design, 89(12), 2626-2642.

Martinho, A., Matos, H., Gani, R., Sarup, B. \& Youngreenc, W. (2008). Modelling and simulation of vegetable oil processes. Food Bioprod. Process., 86(2), 87-95.

Ministerio de Agricultura y Desarrollo Rural. (2010). Empresarización de actividades agropecuarias. Bogota, Colombia.

Morad, N. A., Mustafa, A., Panau, F. \& Yew, T. W. (2000). Liquid specific heat capacity estimation for fatty acids, triacylglycerols, and vegetable oils based on their fatty acid composition. J. Am. Oil Chem. Soc., 77(9), 1001-1005.

Niir, B. (2002). Modern technology of oils, fats and its derivatives. New Delhi: Asia Pacific Business Press Inc.

Noureddini, H., Teoh, B. \& Clements, L. D. (1992a). Densities of vegetable oils and fatty acids. J. Am. Oil Chem. Soc., 69(12), 1184-1188.

Noureddini, H., Teoh, B. \& Clements, L. D. (1992b).Viscosities of vegetable oils and fatty acids. J. Am. Oil Chem. Soc.,69(12), 1189-1191.

Panreac Química S.A. (1999). Métodos analíticos en alimentaria ácidos y grasas. Barcelona: Centre Telemamactic Editorial.

Park, Y., Chang, P. \& Lee, J. (2010). Application of triacylglycerol and fatty acid analyses to discriminate blended sesame oil with soybean oil. Food Chem., 123(2), 377-383.

Perry, E., Webwe, W. \& Daubert, B. (1949). Vapor pressures of phlegmatic liquids. I. Simple and mixed triglycerides. J. Am.Chem. Soc., 71(11), 3720-3726. 
Phillips, J. C. \& Mattamal, G. J. (1978). Effect of number of carboxyl groups on liquid density of esters of alkylcarboxylic acids. J. Chem. Eng. Data, 23(1), 1-6.

Rodríguez, M., Galan, M., Muñoz, M. \& Martin, R. (1994). Viscosity of triglycerides + alcohols from 278 to $313 \mathrm{~K}$. J. Chem. Eng. Data, 39(1), 102-105.

Santana, G., Martins, P., de Lima, N., Batistella, C., Maciel, R. \& Wolf, M. M. (2010). Simulation and cost estimate for biodiesel production using castor oil. Chem. Eng. Res. Des., 88(5), 626-632.

Santori, G., di Nicola, G., Moglie, M. \& Polonara, F. (2012). A review analyzing the industrial biodiesel production practice starting from vegetable oil refining. Applied Energy, 92: 109-132.

United States Energy Information Administration. (2011). IndexMundi, world biodiesel consumption by year. United States of America.

West, A. H., Posarac, D. \& Ellis, N. (2008). Assessment of four biodiesel production processes using HYSYS ${ }^{\circledR}$. Plant. Bioresource Technology, 99(14), 6587-6601.

Zong, L., Ramanathan, S. \& Chen, C. (2010a). Fragmentbased approach for estimating thermophysical propierties of fats and vegetable oils for modeling biodiesel production processes. Ind. Eng. Chem. Res., 49(2), 876-886.

Zong, L., Ramanathan, S. \& Chen, C. (2010b). Predicting Thermophysical Properties of Mono- and Diglycerides with the Chemical Constituent Fragment Approach. Ind. Eng. Chem. Res., 49(11), 5479-5484.

\section{AUTHORS}

\section{Diana-Carolina Cruz-Forero.}

Affiliation: Universidad Industrial de Santander. Ing. Química, Universidad Industrial de Santander. e-mail: carito_xvi@hotmail.com

\section{Oscar-Andrés González-Ruiz.}

Affiliation: Universidad Industrial de Santander. Ing. Químico, Universidad Industrial de Santander. e-mail: andreruiz636@hotmail.com

\section{Luis-Javier López-Giraldo.}

Affiliation: Universidad Industrial de Santander. Ing. Químico, Universidad Nacional de Colombia. Ph. D. Química, Bioquímica y Ciencias de Alimentos, Universidad Nacional de Colombia. e-mail: 1jlopez@uis.edu.co 


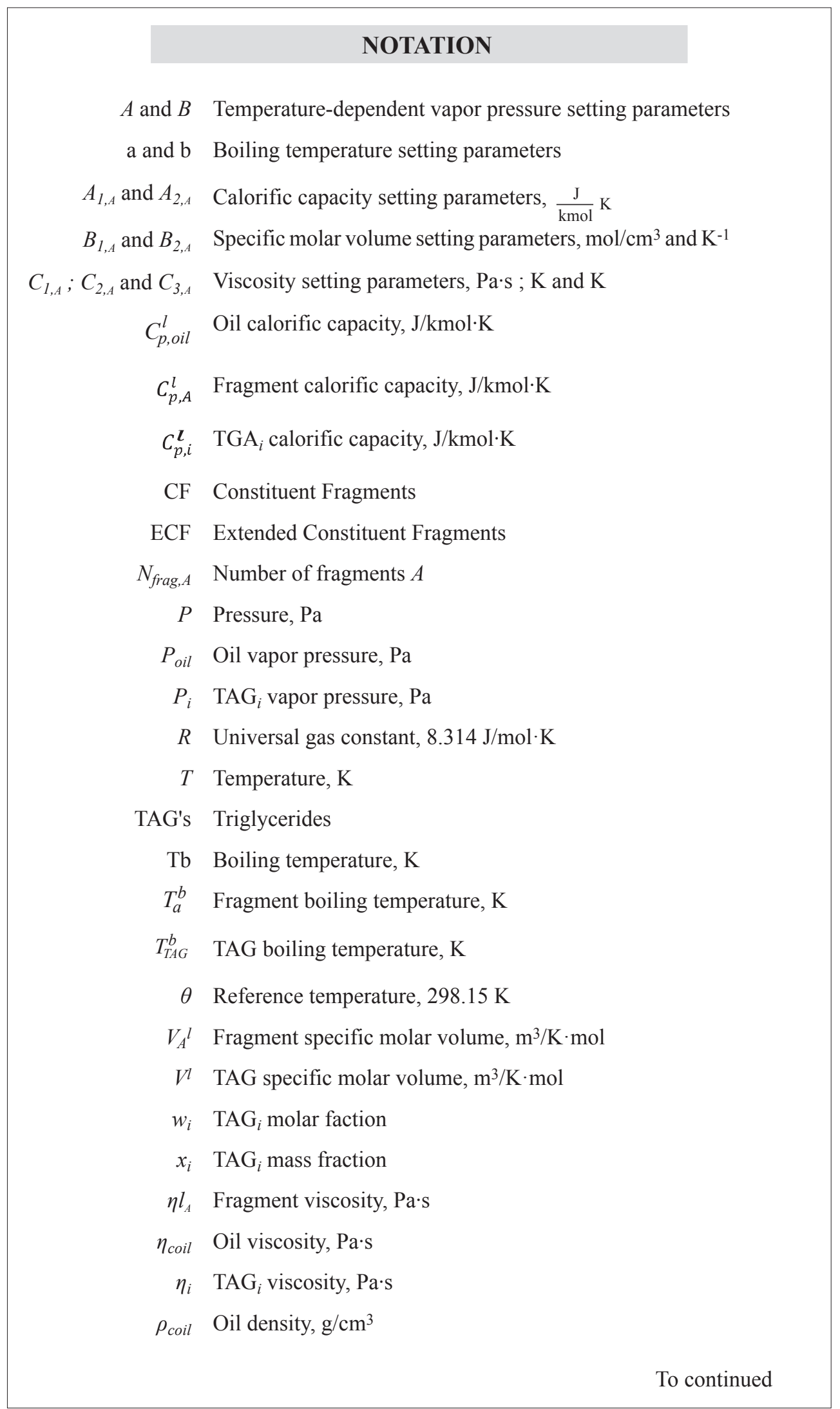


$\rho_{i} \quad$ TAG density, $\mathrm{g} / \mathrm{cm}^{3}$

$\Delta G_{\theta, A}^{v a p}$ Gibbs free energy of vaporization of the fragment at reference temperature, $\mathrm{J} / \mathrm{kmol} \cdot \mathrm{K}$

$\Delta G_{\theta}^{v a p}$ Gibbs free energy of vaporization at reference temperature $\theta, \mathrm{J} / \mathrm{kmol} \cdot \mathrm{K}$

$\Delta H_{\theta, A}^{v a p}$ Vaporization enthalpy of the fragment at reference temperature $\theta, \mathrm{J} / \mathrm{kmol} \cdot \mathrm{K}$

$\Delta H_{\theta \text { oil }}^{\text {vap }} \quad$ Vaporization enthalpy of the oil at reference temperature $\theta, \mathrm{J} / \mathrm{kmol} \cdot \mathrm{K}$

$\Delta H_{\theta, i}^{v a p} \quad$ Vaporization enthalpy of the $\mathrm{TAG}_{i}$ at reference temperature $\theta, \mathrm{J} / \mathrm{kmol} \cdot \mathrm{K}$

$\Delta H_{\theta}^{v a p} \quad$ Vaporization enthalpy at reference temperature $\theta, \mathrm{J} / \mathrm{kmol} \cdot \mathrm{K}$ 